\title{
Glenn Gould: The Idea of South by North Darrel Mansell
}

ON A CITY BUS IN TORONTO, on his way to the memorial service for Glenn Gould, a friend of Gould's found himself in the company of a gentleman from Washington, D.C.. The gentleman wasn't a musician, nor did he have anything directly to do with music. Indeed he was a lawyer, who had taken time from a busy schedule (he was to argue a case before the Supreme Court in two days and was still working on the brief) to pay that tribute in a cold Canadian city on a blustery, showery October afternoon, among strangers, to a man he'd never met. Gould's friend asked him why. Because, the lawyer said, he thought T. S. Eliot and Glenn Gould were the two greatest figures of the twentieth century. From the general public, quite a tribute to a pianist.

Gould is certainly one of the greatest pianists who ever lived. But his greatness is cluttered with distractions: Gould the pop philosopher with his meandering opinions about technology and cruelty to animals; Gould the flamboyant radio, television and film personality wearing funny hats and impersonating self-invented characters with funny names and accents; Gould the writer of convoluted essays in Floridian prose on such subjects as the Moog Synthesizer, Petula Clark and-always-himself; Gould the enfant terrible of interviews with his outrageous pronouncements on music and composers he doesn't like; Gould the creator of elaborately spliced, finicky, dauntingly complex and uninteresting radio documentaries; Gould the visionary inventor of do-it-yourself tape kits and conduct-ityourself playback equipment for the making of personalized home music; Gould the tinkering experimenter with hybrid pianos; Gould the preposterous eccentric with his vials of pills, bottles of Poland water, arrowroot cookies, his galoshes, overcoats, gloves and tweed caps worn indoors; Gould the self-conscious and crafty recluse, unreachable, untouchableGould the muffled genius.

Keats' genius is evident in his letters even if he had written no poetry. Gould away from the piano is mildly amusing, also annoying and harebrained-a gifted, irritating adolescent. Fitful flashes of brilliance do sometimes penetrate upwards through the lush and twining verbiage of a 
Gouldian essay: a reference to nineteenth century music critics who saw in "those massive, glaciated choruses" in the Saint Matthew Passion or the B Minor Mass" insoluble, if not indeed unperformable, enigmas"; a stunning observation on The Art of the Fugue that "despite its monumental proportions, an aura of withdrawal pervades the entire work. Bach was ... withdrawing from the pragmatic concerns of music-making into an idealized world of uncompromised invention." But Gould's genius is almost all in his pianism, the rest merely curious, restless distraction - highly revealing of him the person, but of his genius revealing almost nothing at all.

Nor does his pianism always reveal genius either. Arthur Schnabel got into whatever he recorded the qualities that made him great (melodic lines for instance that come in as if they had previously been circling through the music unheard, like comets whose brief arc overhead is only a moment in some distant and stupendous celestial plan). Gould on the other hand sometimes sets himself to music that either repels his genius or actually destroys it. His recording of Grieg's Sonata Number 7 in E Minor could be by almost anyone in the Schwann catalogue. He is utterly lost in and diminished by the huge vacancy of the music. His one organ recording and his Schoenberg piano recordings have even been faulted for poor execution.

His genius shows itself if and when he can clearly articulate the musicgive it what he calls the "secco, pointillistic, détaché line" he likes. Each note has a clean, sharp music-box ping (as in the fast, tense, plucky righthand part in the Gigue section of the Bach Partita Number 1 in B Flat Major; or his breakneck-speed recording of the Scarlatti Sonata in D Major, L 413). His runs are like shattering glass-quick but with each note sharply set off (the seventh variation in the 1981 recording of the Goldberg Variations; the big breathtaking runs in the Brahms Rhapsody in B Minor Opus 79 Number 1). His famous trills (as in the twenty-eighth of the Goldberg Variations) and harplike arpeggios are taut like springmetal under terrific tension (the first and third sections of the Brahms Ballade in D Major Opus 10 Number 2). The sheer nervous energy in his pianism is terrifying. He goes for brash, racy, fast tempi; or (as in the Mozart Fantasy in D Minor K397) ones so perversely slow that the very silences seem stretched, edgy, tortured. Another pianist said that Gould's signature is that he plays everything either too fast or too slow.

He sharply articulates not just the notes in the melodic line, but the 
right and left-hand lines from each other. Usually these are cleanly separated like the voices in a duet (as in the counterpoint of the eighteenth and the short twenty-sixth of the Goldberg Variations; also that famous encore piece the Menuet in the Bach Partita Number 1 in B Flat Major). Gould's playing of counterpoint is sometimes even like two entirely different pieces of music that just amazingly happen to cross, recross and harmonize with each other like motorboats cavorting around a lake. His own left-right neural organization must have been as phenomenal as Napoleon's, who is said to have been able to write letters while carrying on conversations. Gould carried on long animated telephone conversations while reading magazines or learning music scores. He said he listened in his apartment to two radios both turned on but tuned to different stations. $\mathrm{He}$ tells of sitting alone in restaurants eavesdropping on what was being said at three or four nearby tables all at the same time.

He also vividly contrasts and thus articulates the music's phrases, sections and movements. There is a highly dramatic-sometimes melodramatic-emphasis on abrupt differences in tempo (the hair-raisingly energetic beginning of the second of the Goldberg Variations), or in dynamic range (the crashing orchestral crescendoes in his remarkable interpretation of the Brahms Ballade in D Minor Opus 10 Number 1). Music for him isn't a steadily unrolling bolt of silk, as music often seems to be for Walter Gieseking, but a mosaic of sharply etched and highly variegated little pieces crammed together to make a glittering design.

Gould's playing has the effect - on me at least, and perhaps the Washington lawyer-of laying bare the structure of music. Indeed Gould thought of himself as an analyst, an anatomist, of music. He liked to talk about music's "strands," its "backbone." He recommended singling out one strand, one melodic line, as the best way to begin to understand a musical work. I heard him for the first time at a concert at Oberlin College in the late nineteen-fifties. What I knew then about the structure of music was a rumor I'd heard that things tend to repeat themselves. His playing of the Goldberg Variations was my revelation that music does have structure and parts - a bird flying overhead suddenly made transparent, the intricacy of its veins, muscles, bones clear and distinct; a gloomy building suddenly turned to glass. Even composers like Stravinsky and professional musicians like Gina Bachauer have admitted to being visited by such Gouldian revelations (indeed Yehudi Menuhin, having rehearsed with him, said, "It was a revelation."). 
Gould's clarity of articulation seems to have come at a high price. He thought of himself as something of a technician, specializing in structurally complex and cerebral music like that of Bach and Schoenberg which lends itself to such articulation. He liked to present himself as a cool and austere classicist, an Apollonian, a no-more-cakes-and-ale Malvolio frowning on the pulsing sentimentality, the tragic posturing and shallow showmanship of romantic music. (Once, in an interview with Arthur Rubenstein, he foisted off on that elderly maestro's politely mystified but hospitable self the ungratifying role of Gouldian antitype, the Dionysiac pianist.)

Gould took deep satisfaction in thinking of his art as forbiddingly intellectual and severe. He thought of himself as that way too. He claimed to be the "last puritan." He saw himself as isolated in a cold, remote and lonely arctic circle - an anchorite, the self-proclaimed brother-in-solitude of that other modern misanthrope, Howard Hughes. At the very height of Gould's fame, when he was adulated, sought-after and only thirty-two, he abruptly withdrew from the concert circuit. Among the reasons he gave during the subsequent years was that performing had put the "naked fact of your humanity" too much on display; and likewise the audience's humanity, the perspiration of bodies penetrating Gould's own nostrils. He turned to studio recording, which he saw as a way of putting distance between human biology and art, none of the audience's bodily infirmities communicated to him, none of his to them (the master tape can be put together from many different takes to make an errorless and perfect performance-what Gould called the "take two-ness" of studio recording).

Withdrawal into an arctic solitude became for him the spiritual climate necessary to his art - that sharp, ringing clarity. The north of the flat, windswept Toronto landscape with its lowering skies; the coldness of dark blue, battleship gray and black, which he said were the only colors he could stand (he claimed to have been upset as a boy by the vivid technicolor of a Walt Disney film); the utter blankness of a big midtown Toronto hotel where, down dim, muffled corridors, he stayed in a studio with the light shut out, sleeping by day, working by night, eating room-service suppers at six in the morning served by bleary waiters; the echoing emptiness of having withdrawn into winter and the dark ("sooner or later I'm going to spend a winter in the dark"); the vast and awesome desolation (what he called the "Ibsenesque gloom") of Sibelius' Fifth Symphony which extends like frigid, remote, endless musical space behind the Newfoundland characters who tell of their solitude in that radio documentary 
of his which is really a documentary about Gould himself, The Idea of North.

The piano is the most northern, most solitary of musical instruments. Some of the great pianists-Horowitz for instance and Michelangelihave been solitary and withdrawn; Gould surely most of all. His was the schizoid artistic personality (as Geoffrey Payzant observes in his book on Gould) which obsessively needs to control everything, to withdraw from what can't be controlled and to communicate outward only in strictly controlled terms. Gould thought of his own terms as uncompromisingly cerebral; of his music, as that which can be controlled, manipulated, by mind. Indeed it has been remarked that music doesn't happen to Gould, he happens to $i t$. He tends to regiment the music like a Prussian drill sergeant. He jerks the music around. He must at all costs impose his clear, brilliant, articulate logic on the music. He won't let the Mozart piano sonatas creep out into even a little of their bashful warmth and expressiveness. He keeps that in check, going instead for fast, sparkling tinkle where it's the highly organized and opinionated Gould dominating, playing Mozart (an accusation Gould characteristically leveled at himself in a recorded self-interview).

But a fanatical attitude has a way of revealing a repressed attraction toward its very opposite. Such a single-minded dedication to the idea of north passes through its ultima Thule and ends up headed south. Gould's declamatory inistence on the purity of his intellectualism, on the ferocity of his dislike of romantic music, on the utterness of his own isolation, on the extremity of his northernness come together into a personality so artificially definite as actually to have an opposite-which is also present in him. He was fascinated by the music of Wagner, and produced a big, ambitious, lyrical piano transcription of some of it. Gould's one recorded string quartet is, as he acknowledged, decadently romantic and the very opposite of everything he professed to stand for. There is also Gould the ham, the Liszt-and-Paganini virtuoso who undertook titanic performances like the absurd and fascinating Liszt piano transcription of Beethoven's Fifth Symphony-Gould the closet romantic.

No one wanting to be identified as a hermit was ever so up on the world's affairs as Gould-a willful boy sulking in his room but peeping through the keyhole at what's going on down the hall. He knew the latest pop tunes, had his favorite singers (Petula Clark, Barbra Streisand), idolized Leopold Stokowski, who had given up public concerts to go to Holly- 
wood (Gould himself produced the music scores for a number of films, one of them Slaughterhouse Five), wheeled and dealed in goldmine stocks, drove around in fancy cars (windows up, heater and radio on full blast), plugged into the with-it world of TV Pepsi commercials.

He wanted to connect. It wasn't that his solitude made him lonesome (though the narrator of The Idea of North says the north does that to people). Muffled in his overcoat, holed up in windowless recording studios or darkened hotel rooms, cruising the Toronto streets alone in his Lincoln, haunting cavernous half-closed Ontario northshore resorts in the cold off-season, he could carry on an intense, even passionate affair with the world through the wires of recording equipment, the telephone, television, and radio. He was fascinated by radios. He remembered as a boy riding home from his parents' vacation house north of Toronto on dark snowswept Sunday evenings listening to Beethoven symphonies on the car radio. He remembered his youthful wonder that through the delicate cat's whisker and headphones of a crystal set the human voice could be heard (as the humming and vocalizing of his own can be heard in the background of many of his recordings). He remembered going to the CBC Toronto studios for the first time to make a broadcast - his fascination with the radio microphone as something he could emotionally, intimately relate to.

Gould wanted to have the world, and the world to have him, through a wire-everything translated into electrical signals passed back and forth from one dark cell to another. He liked an idea of the modern theologian Jean LeMoyne that technology doesn't stand in the way of human contact but actually facilitates it, makes it more direct and immediate, by eliminating from it aggressiveness and self-consciousness. Such contactthrough-technology is no longer sensual, but isn't merely intellectual and certainly isn't passionless (Gould referred to Sibelius as a "passionate but antisensual" composer). Through the wire comes not just the nervous taut articulation of intellect, but passion-pure human passion with all the odors, grunts, grimaces relieved of body and turned to electricity. Gould in the dark alone could tune in on the world's passion (he shrewdly remarked that Petula Clark's voice, which he listened to on his car radio, is middle-class culture's nice girl coyly saying she's leaving home-cautiously, tentatively - for the big bad world of sex). The world in turn could tune in on Gould's passionate affair with it. 
In the next-to-last year of his life he recorded some Brahms ballades and rhapsodies (earlier he had recorded ten Brahms intermezzos). That late recording is eerily otherworldly in musical conception and is indeed Gould's other world-the palinode of someone whose cool and keen intellectual purposefulness has turned itself inside out to reveal the power and beauty of the other side. He had said that he saw romanticism as an effort to overcome the limits of quantification, the arithmetical and cerebral spirit, of classical music. So it is that in the Brahms ballades and rhapsodies Gould is in music he can't entirely subdue into sharp, ringing articulate shape by the sheer power of intellect. The music is reluctant to be manipulated. It hangs together in big, amorphous phrases like clouds scudding by, in gigantic lumps and clumps of harmony like hillsides rising out of the gloom (Gould had admitted in the cocksure years of his Mozart recordings that he'd spread out some of the sonatas' chords into arpeggios so that he could articulate the notes one by one). The Brahms pieces suggest matter over mind, dumb nature's forms themselves not much given to articulation - the sullen burble of the swamp, the bristling little arpeggios, the snatches of counterpoint that come and go in the music only to be lost again in the Alles.

Gould the analyst, the dominant thinker, can't play such music, he has to play along, collaborating, sharpening up the edges here and there, heightening a crescendo, but for the most part letting those haunting forms deliver themselves through him. He'd commented on Beethoven's late piano sonatas that they can be manipulated to one's purposes, but that with music so stupendous "it is the happier diversion not to try." In Gould's last years it became easier and easier not to try; easier to surrender that intense, intellectual purposefulness, easier to play along-another revelation, the taut, nervous, finicky, control-obsessive Gould sitting at last more or less content in the lap of ample mother nature.

Not long before he died he said that his years of solitude were the happiest of his life. Someone who knew him remarked that Gould had come to terms with his genius. For years seen by almost no one, roaming chilly and deserted landscapes, or in the midst of tape transports and television monitors in a dark room down labyrinthine corridors in a Toronto hotel, he was carrying on an affair. The kind of affair we have with the telephone operator. The kind of affair a character is having in one of Hemingway's stories. Mr. Frazer is in a hospital in Hailey, Montana. In the deep, lone- 
some silence of the night he can get Seattle, and later, Minneapolis on his bedside radio. Because of the difference in time zones it's already morning in Minneapolis and he can listen to some studio musicians who call themselves the Morning Revellers. He likes to imagine how the Revellers look getting off the streetcar with their instruments before daylight on their way to the studio. He'd never been to Minneapolis and believes he probably never will go there, but in the lonely darkness of his Montana hospital room the Revellers' world is alive for him.

So it was with Gould. That solitary, strange, cold, cerebral genius had found a way to carry on a passionate friendship, a shy romance, with the sprawling, unkempt, bustling world outside, though he'd probably never go there: the blandishments the world had for him, his for it, going back and forth for the most part through a thin wire. 